\title{
Mapping the distributive environmental justice of urban waters
}

\author{
ARTO VIINIKKA, RIIKKA PALONIEMI AND TIMO ASSMUTH
}

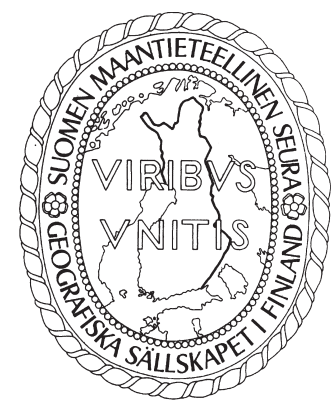

Viinikka, A., Paloniemi, R. \& Assmuth, T. (2017) Mapping the distributive environmental justice of urban waters. Fennia 196(1) 9-23.

https://doi.org/10.11143/fennia.64137

$\boldsymbol{У}$

In this paper, we identify patterns of distributive environmental justice in the Helsinki Metropolitan Area (HMA) in terms of spatial proximity of urban waters, as a potential provider of a diverse set of environmental goods and well-being. Our focus is on the question how equally these benefits are distributed in HMA? To answer this we apply a GIS-based clustering analysis with spatial statistics to map the good and deprived access of different socio-economic and demographic groups to urban blue. We use income, education, language and age as factors to delineate residential areas and found not only differences in how various population groups are located in the four different municipalities of the HMA, but also differences in group distances to the nearest water areas. Results show that high income and high educational background, Swedish language and high age are factors more frequently related to living closer to water areas. At the same time, children, foreigners, and people having lower economic status tend to live further away from urban blue. This is important knowledge to be integrated into urban planning. The recognition of lacking opportunities suggests more consideration towards these aforementioned population groups to reduce inequality and to ensure just distribution of accessible and usable urban nature in the HMA.

Keywords: distributive environmental justice, urban water, socio-economic and demographic group, urban planning, ecosystem services, GIS

Arto Viinikka, Riikka Paloniemi \& Timo Assmuth, Finnish Environment Institute (SYKE), Mechelininkatu 34a, P.O.Box 140, Fl-00251 Helsinki, Finland. E-mail: arto. viinikka@ymparisto.fi, riikka.paloniemi@ymparisto.fi, timo.assmuth@ymparisto.fi

\section{Introduction}

Urbanization brings environmental pressures through the intensified competition for urban space and for the goods and ecosystem services produced in this space, in both terrestrial and aquatic settings (Ernstson 2013). Artificially altered 'tamed' water elements are mostly opted for in urban development. Small urban waters are channeled through underground piped routes, or in other ways, in order not to destroy buildings and other grey infrastructure and simultaneously to provide preferred ecosystem services (for a definition, see Millennium Ecosystem Assessment 2005), such as storm water or waste water management (Millennium Ecosystem Assessment 2005, 67). At the same time, increased attention is also being paid to the recreational and esthetic values of urban waters, in short urban blue, and to its various roles and functions in promoting and maintaining health and wellbeing (Tzoulas et al. 2007; Deplege \& Bird 2009; White et al. 2010; Wolch et al. 2014).

In this paper, we approach the distribution for urban space and ecosystem services from the perspective of distributive environmental justice. Traditionally environmental justice has been focusing on the health implications caused by the contaminated land or unwanted land use usually 
situated closer to poor population groups (Davis et al. 2012, cit. Bullard 2000). More recently, the term has been applied to the discussion about the fair distribution and equal access of the environmental benefits and well-being (Boone et al. 2009; Jennings et al. 2012). Cambell $(1996,303)$ advocates that social justice should be understood as "striving towards a more equal distribution of resources among social groups across the space of cities and of nations" - placing this study in the frames of distributive environmental justice. While procedural justice captures the fairness of decision-making processes (including the methods, practices, agency and recognition of the participating actors), distributive justice focuses on the fairness of their outcomes, including the distribution of resources and the (dis)services they produce (on these dual aspects of environmental justice, see Tyler 2000; Agyeman 2005). The distributive aspect has been increasingly studied, for example, in connection with the perceptions of justice across scales (Patrick et al. 2014), with the diversity of ecosystem services (Aragão et al. 2016) and with the regulation of their international distribution (Davidson 2012). Along with such studies, an important topic has been the distribution of ecosystem services and their accessibility in relation to the social-demographic characteristics of populations living in the area (e.g. Kabisch \& Haase 2014). Here, we continue this line of research with a focus on distributive justice by exploring the potential patterns of socio-economic and demographic characteristics related to urban waters.

The distributive environmental justice related to urban water raises the question of how equally or equitably ("justly") urban blue is spatially distributed in relation to the different population groups who potentially benefit from it, particularly those who inhabit the surrounding areas. The equal distribution of urban green and blue areas is relevant because of the recreational, esthetic and health benefits that frequent use of these areas brings to people (e.g. von Hertzen et al. 2011). There are however increasing challenges related to the just distribution of green and blue space in urban areas; Ernston $(2013,8)$ even argues: "if urban nature comes with benefits, there is almost certainly an uneven social production of such ecosystem services". Especially from the perspective of distributive environmental justice, it is relevant to recognize the population groups whose access to urban nature areas is particularly restricted or whose access is of particular relevance for their increased needs for access. Kabisch and Haase (2014) found that in the certain inner city sub-districts of Berlin with relatively high percentages of immigrants and a high population density there was less access to urban green spaces, and in their case area Tempelhof, green areas were more frequently used by Germans, even though a high percentage of residents in the area were immigrants. In addition, people aged over 65 years did not frequently visit the areas. Similar findings regarding the distribution and accessibility of green areas were observed in studies conducted in South-Africa and North-America where higher income seemed to correlate the amount and condition of urban green (Heynen et al. 2006; McConnachie et al. 2008). These findings encourage researchers to pay further attention to the accessibility of urban spaces to immigrants and the most vulnerable age groups, including children and adolescents besides elderly people.

Rather often, the analyses of environmental justice have focused on green areas (Heynen et al. 2006; Sister et al. 2006) although in many coastal areas like Helsinki, the importance of the shoreline for environmental justice is evident. Additionally, water bodies, such as lakes and rivers, play a significant role for the well-being of residents and visitors, providing positive preferences and experiences (Völker \& Kistemann 2011), while smaller water bodies, such as streams and ponds, have a significant potential in providing environmental amenities. A Finnish study on the perceived significance of small water courses and streams in Helsinki concluded that streams are important especially for recreational purposes and as playgrounds, and, accordingly, that they should be preserved for future generations (Lehtomäki 2015, 33). More specifically, in a recent study of the perceptions of inhabitants in the Helsinki Metropolitan Area (HMA) on the quality of water areas it was found that the preferences for urban waters are not only related to the value of existing water areas, but also to the willingness to travel there and to the travel costs involved (Laatikainen et al. 2015). However, when examining the quality of nature in terms of preference, willingness and cost, attention should be paid to distributions within populations and especially to those that have limited capacities for transportation, such as small children and the poor. 
The HMA is constantly growing in population and much of the recent development in the HMA has been planned and implemented in coastal locations. It has been reported that urban water areas near homes are perceived to increase their amenity value (Asakawa et al. 2004). This perception can increase the demand and pricing of housing areas (Luttik 2000) and can result in segregation and non-equity (Schaerer \& Baranzini 2009). Growing inequalities in urban areas that are continuously in focus in global discussions are also visible in the HMA (Vilkama 2011; Vaattovaara \& Kortteinen 2014; Vilkama et al. 2014). According to Vilkama and others (2014), there are three main reasons behind this development: 1) labor force migration after WW2 has made the HMA one of the fastest growing metropolitan areas in Europe; 2) the population structure has changed due to increasing immigration; and 3) income differences have grown after the economic depression in the late 1990s. Recent study by Kortteinen and Vaattovaara (2015) states that the divergence between different population groups continues to grow in HMA and people with low median income, low level of employment, and low level of education more often live in neighbourhoods with high concentration of ethnic minorities. These changes and the associated diversification of population groups and lifestyles are creating new environmental pressures and altering the demand for the use of urban water and green areas. Thus, it is important to understand the implications of these changes in urban environment in terms of environmental justice.

In this article we identified the patterns of distributive environmental justice in the HMA in terms of spatial proximity of urban waters, as a potential provider of a diverse set of environmental goods and well-being for the residents. Building on the evidence that people with good access to green or blue space are more likely to use it (Wolch et al. 2011; Spinney \& Millward 2013; Laatikainen et al. 2017), our aim was to map residential areas of good and deprived access of different socio-economic and demographic groups to urban blue. Toward this aim, we selected total of four socioeconomic and demographic factors to spatially delineate homogenous residential areas and applied statistical tests to see how factors influencing socioeconomic status (income, education) and language and age have an impact on the possibility to live close urban water areas.

\section{Studying environmental justice in the Helsinki Metropolitan Area}

The spatial focus of our study was the Helsinki Metropolitan Area (HMA), including the capital of Helsinki and the surrounding municipalities Vantaa, Espoo, and Kauniainen which can be seen to function together as one urban regional unit (Fig. 1). In the region during recent years, water issues have gained increased attention in policy making and in general as well as scientific awareness. The Water Framework Directive of the EU (2000/60/EU, OJ L 327) was an essential milestone in water management and is also visible in local policies, strategies, plans and other instruments in several sectors, thematic areas and parts of Helsinki. These instruments and actions are mainly driven by the objective of improving the ecological status of urban waters, but also by goals such as developing tourism, strengthening local identity, improving recreational opportunities and promoting public health (Helsingin kaupungin rakennusvirasto 2007). These objectives come closer to the notion of cultural ecosystem services, which is one essential motive for analyzing and improving distributive environmental justice (Daniel et al. 2012).

Urban blue in this context included surface waters ranging from the Baltic Sea to lakes and rivers. Helsinki and Espoo have long coastlines, which dramatically affect the presence of water in the areas, and the entire image of the HMA as a coastal region. In addition to coastal areas, other urban waters, including for example the River Vantaa (Vantaanjoki), are popular recreational sites for urban dwellers in the area (Laatikainen et al. 2015). The significance and importance of other smaller water bodies have been also taken into consideration in the development of the urban areas (Helsingin kaupungin rakennusvirasto 2007), and accordingly included in our analysis.

For delineating the urban blue, we used data from the Finnish Environment Institute maintained Ranta10 Database that is freely open data and can be downloaded from the Environmental Administration web pages (http://www.syke.filopendata).

The urban grid structure (YKR) of 250 meter square was used as a spatial unit for this study. The YKR dataset is a Geographic Information (GI) based reference and monitoring system of spatial 
structure and urban form. It includes the socio-economic and demographic statistics of the population in Finland that are maintained by the Finnish Environment Institute (SYKE) and it has been considered having adequate spatial resolution on a regional scale (e.g. Kekez 2015; Laatikainen et al. 2017). The source data grid was not populated with values for every cell and the cells that did not contain socio-economic and demographic values (i.e. no population located in that cell) were therefore not part of the analysis.
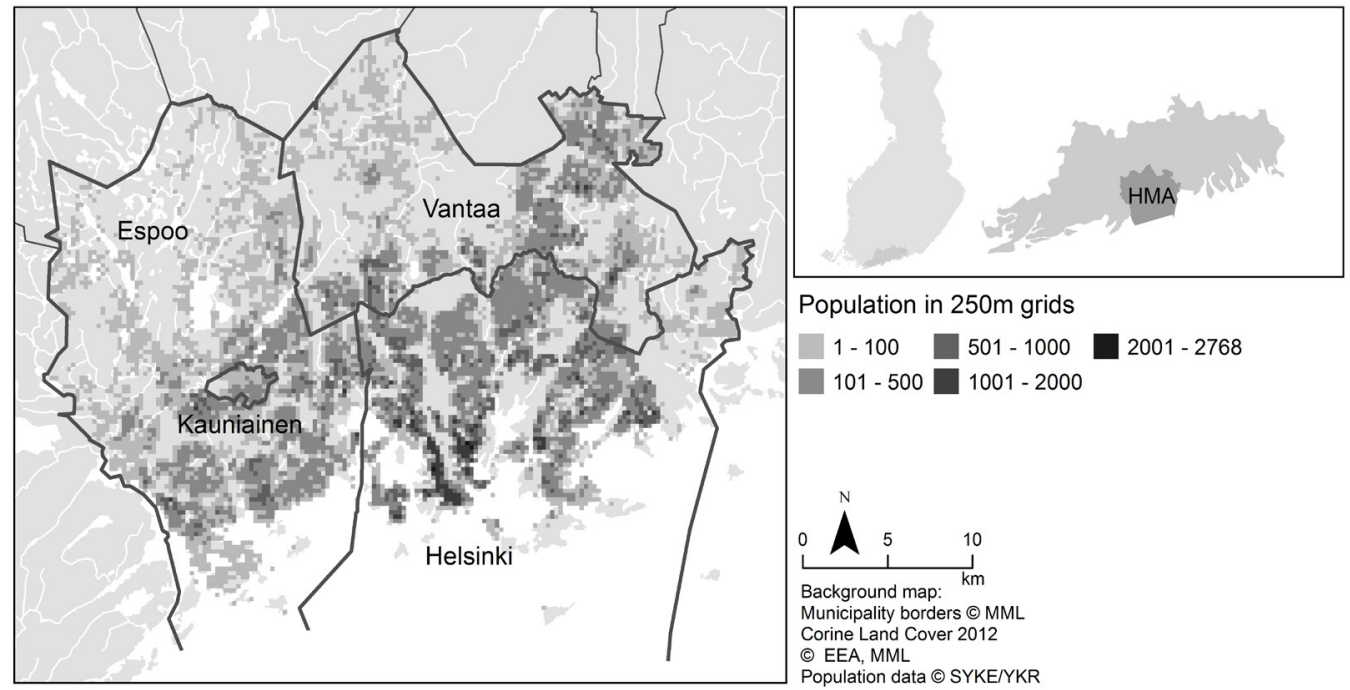

Fig. 1. Map of the study area, with population distribution (graded) and water areas (uncolored surface) in the Helsinki Metropolitan Area (HMA).

\section{Measured socioeconomic-demographic factors}

As socio-demographic factors, we measured age, language, income and education (Table 1).

Age is a factor affecting both the preferences and the possibilities for choosing the residential area. According to the latest "Asukasbarometri" in Finland (Residents' barometer - survey on urban residential environments), more and more Finns want to live in an urban environment close to services, leisure opportunities and good transportations (Strandell 2017). This requires particular attention to the access to urban green and blue especially among children and the elderly, as they are capable of walking shorter distances. Study highlighting the need for green space Barbosa and colleagues $(2007,194)$ concluded: "those who appear to enjoy the greatest access to green space include those who might be considered in most need of publicly provided green space benefits, such as the least affluent and the elderly." Age also plays a remarkable role in how important the amenities and affordances of the residential area are to health and well-being (Corraliza et al. 2012; Chawla et al. 2014; Dadvand et al. 2015). Nearby walkable green spaces are reported to promote the health of senior citizens in densely populated urban areas (Takano et al. 2002), while children's exposure to green space microbes develops and strengthens their immune system (Ruokolainen et al. 2015). Among the age groups, we paid particular attention to children and adolescents $(<18$ years), and the elderly (>65 years).

Foreign urban inhabitants are another citizen group that needs to be better accounted for (Kabisch \& Haase 2014). This group is probably becoming even more relevant due to the recent inflow of asylum seekers to Europe. Immigration is a long-term process, molding cities and shaping urban patterns. This is a heterogeneous group with different backgrounds and reasons for immigration. Languages were used as an indicator for this group. There are two national languages in Finland, Finnish and Swedish. Even if nearly $<10 \%$ are native Swedish speakers in large parts of 
Table 1. Analyzed socio-economic and demographic factors based on the YKR dataset.

\begin{tabular}{l}
\hline Factor \\
\hline Age below $18[\%]$ \\
Age over $65[\%]$ \\
Finnish language [\%] \\
Swedish language [\%] \\
Foreign language (incl. all but domestic languages) [\%] \\
Household median income proportional to household size [€] \\
Proportion of total employed with primary education [\%] \\
Proportion of total employed with tertiary education [\%] \\
\hline
\end{tabular}

the HMA, the position of this minority is relatively well-established. We therefore used a foreign language as a first language as a proxy for (ethnic) foreignness.

Finally, as key socio-economic factors we included the level of income and education in the analysis as they are highly linked to people's socio-economic status (SES). Although green environments have a significant beneficial effect in all education groups, it is reported to be stronger for people with a lower SES (Maas et al. 2006). However, there is evidence that lower SES neighbourhood lack nearby green areas comparing to high SES areas (Mitchell et al. 2011; Wen et al. 2013), thus we wanted to separately analyze high and low SES residential areas. The level of income used here is the household median income in an YKR grid divided by the average household size. Without proportioning the income factor by household size, grids mostly having large households would be biased. Education includes the proportion of employed people with primary or tertiary education. In Finland, primary education includes a maximum of nine years of compulsory studies whereas tertiary education refers to a degree in an university of applied science or a master's degree at university. Of these, income might be the most crucial individual factor determining the place of residence through economic resources, while education has other kinds of influences on social preferences, behaviors and cultural identities, including those linked to engagement with nature. However, in this study these aspects are not included because of their subjective character and all the water areas are considered equally important in the environmental justice point of view.

\section{Analysis of the just distribution of urban waters}

The distribution of urban waters in HMA was analyzed following a two-stage procedure: First, we mapped how the population groups were clustered in terms of the socio-economic and demographic factors and how the clusters were situated in the area; second, we investigated how the clusters were spatially distributed in terms of proximity to the urban blue in the area.

In order to identify and delineate the residential clusters, we mapped the similarity in chosen population groups by measuring the spatial autocorrelation of income, education, language, and age. When high value grids were surrounded by other high value grids, the cluster was referred to high, and when low value grids were surrounded by other low value, the cluster was referred to low. The spatial autocorrelation is a measure of the spatial dependence based on the Tobler's first law of geography: "everything is related to everything else, but near things are more related than distant things" (Tobler 1970, 236), meaning that nearby observations exhibit more similar properties compared to observations in random space. We used a two-step analysis where we first assessed the variable for global indices to measure the similarity of the population groups using the global Moran's Index, which is an inferential formal statistics method that can be viewed as an explorative 
spatial analysis method. If this statistic showed spatial autocorrelation as clustering patterns in the data, we proceeded to also test and map the clustering using a Local Indices for Spatial Autocorrelation (LISA). LISA identifies neighboring features with similar (i.e. clusters) or dissimilar (i.e. outliers) values in the data and is therefore able to offer a preliminary identification of statistically significant clusters or outliers in space (Anselin 1995). We used the k-nearest neighbour (knn) with eight neighbour grids in our analysis where the values of every grid in the study area were compared to eight neighbouring grid values. The grids were classified as low or high value clusters if values around the selected feature were more similar to the average of the eight neighboring values compared to values in random space.

We defined the Local Moran's Index significance by its p-value. A p-value smaller than 0.05 , for a number of 999 permutations, was considered significant. We used the software GeoDa (Anselin et al. 2006) with the option of a randomization test, to produce reference data.

In order to test how the high and low value clusters were distributed in terms of distances to urban waters, we used a formal statistical method, the Kruskall-Wallis test. This test is a rankbased nonparametric test developed for non-normal populations where the null hypothesis can be set to measure the similarity of cluster populations as long as the data groups are identically shaped and scaled (McDonald 2014, 157-164). It is a powerful tool for comparing and statistically testing differences between groups, and in our case how the distance of urban waters differs between clusters.

The clusters were analyzed using equal sample sizes based on the lowest number of formed clusters in each population groups. The distances of the clusters to the nearest water areas were applied in formula:

$$
H=\frac{12}{N(N+1)} \sum R_{i^{2 \div n_{i}}}-3(N+1)
$$

\section{Equation 1}

Where $\mathrm{H}$ is the Kruskall-Wallis test statistic, $\mathrm{N}$ is the total sample size, $\mathrm{n}_{\mathrm{i}}$ is sample size per group and $\mathrm{R}_{\mathrm{i}}$ is the rank sum of distances per group.

We further used Dunn's post-hoc non-parametric pairwise multiple comparisons test to rank the individual clusters based on the distance to the closest water area and visualized the results by using plotgraphics for a more intuitive interpretation (Wickham 2009). Dunn's test is az-approximation of the group rank sum statistics and in this case was used to identify if cluster distances differ among the income, education, language and age clusters (Dunn 1964; Pohlert 2016). The null hypothesis was that the studied high value cluster, for example income distances to nearest water areas did not differ from the low value income cluster distances. In the other words, the probability of observing a randomly selected larger distance value from a high cluster i comparing every low cluster $\mathrm{k}$ equals one half. If selected value from cluster i was larger more frequently than $50 \%$ of cases the null hypothesis was rejected that indicates differences between the high and low cluster distances to water. Dunn's test was applied using Rstudio.Ink version 3.2.5 (R Core Team 2013) with the package “Dunn.test" (Dinno 2016).

\section{Distributive environmental justice in the Helsinki Metropolitan Area}

\section{Spatial distribution of socio-economic and demographic residential clusters}

Figure 2 encapsulates the cluster maps representing the spatial distribution of residential clusters. The maps consist of four different factors with two different classes: 1) high value grids surrounded by other high value grids (hereafter high), and 2) low value grids surrounded by other low value (hereafter low)

Considering the HMA as a whole, there were similarities in the geographical patterns of how population groups were located in the area (Fig. 2). From the language groups, high clusters of 

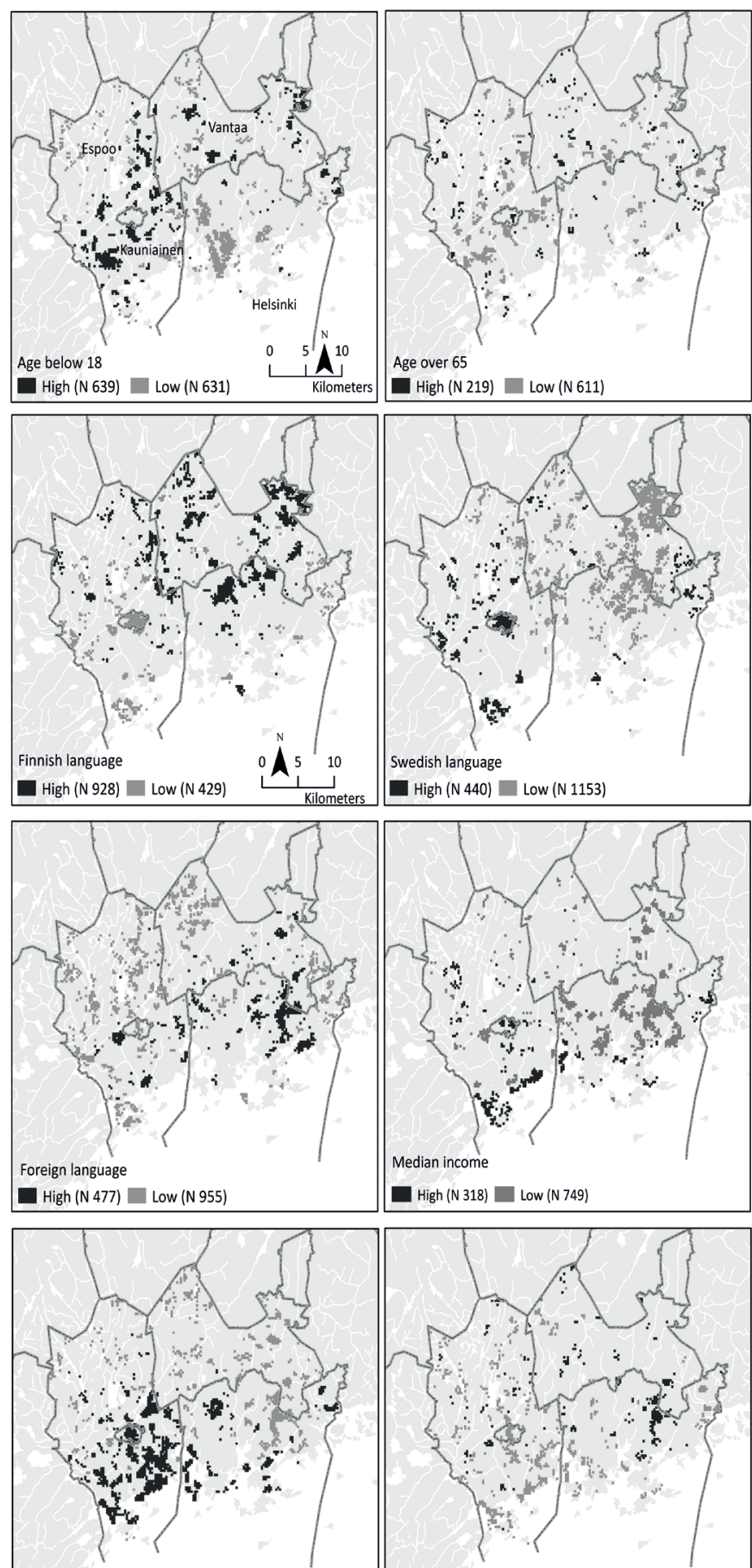

High education

High (N 947) Low (N 644)

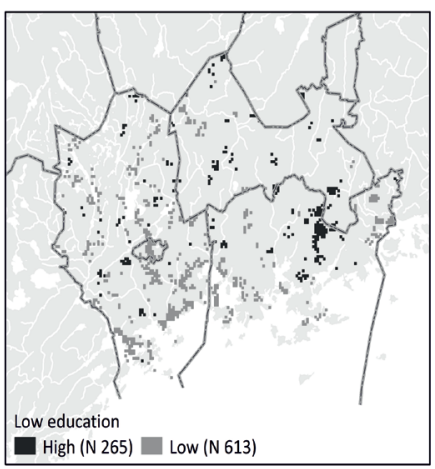

Fig. 2. Spatial distribution of statistically significant $(p<0.05)$ high and low value residential clusters in the Helsinki Metropolitan Area (HMA).
Finnish speaking population were concentrated to Northern parts of the area, whereas Swedish speaking population had a weight in Westerns parts. Correspondingly, foreign language groups were found in Southern parts of the area. Age groups, however, were more spatially dispersed and especially people over 65 years of age that reside all over the area. In the southern coastal area people with higher socioeconomic status in terms of median income and education were present.

While there were spatial differences considering the geographical locations of the population groups, the clustering varies also remarkably between the administrative borders of the municipalities in the HMA (Fig. 3). Espoo had the highest percentage of clusters in nine population groups including high value clusters of: age below 18 years (63\%), age over 65 years (43\%), Swedish language (57\%), median income (69\%) and a high level of education (67\%). Furthermore, most of the low value clusters of age over 65 years (55\%), Finnish language (57\%), foreign language (51\%) and a low level of education (62\%) were also concentrated in Espoo. The abundancy of high median income and high education cluster that indicates higher socio-economic status was concentrated near the coastal areas whereas both studied age groups were more evenly distributed to the whole city area.

Those groups characterized by speaking foreign language mostly lived in Helsinki (55\%), while those characterized by speaking the Finnish majority language mainly resided in Vantaa (52\%). Those groups speaking Swedish as a native language were mostly found to be living in Espoo and least in Vantaa. In Helsinki and especially in the eastern suburbs, over $20 \%$ of the total population spoke a foreign language and 35\% of 


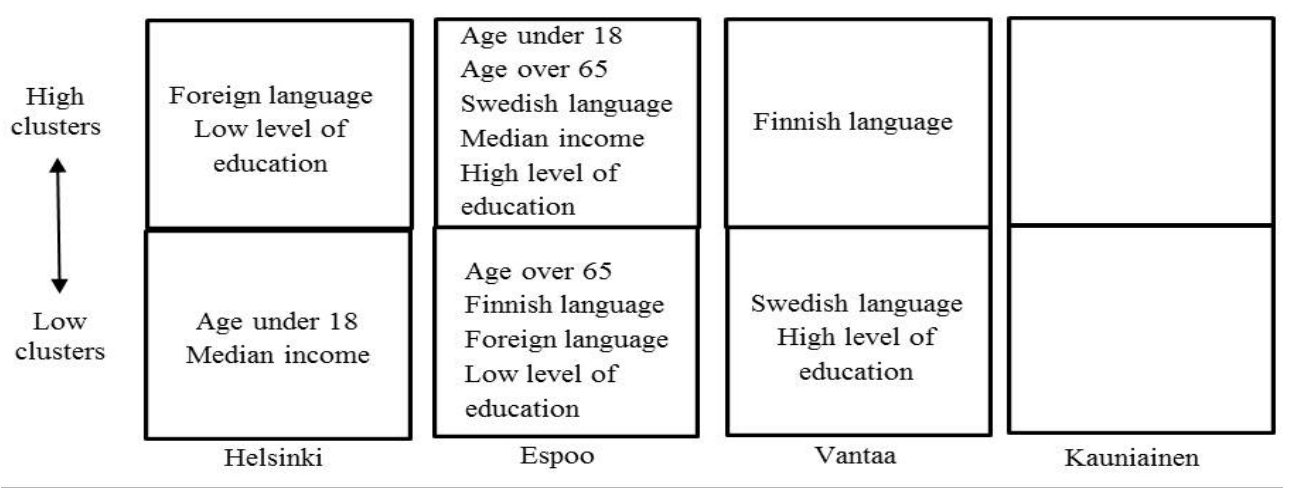

Fig. 3. Cluster distribution according to count frequency in the municipalities of Helsinki Metropolitan Area (HMA).

Table 2. Differences in distance to water areas among socio-economic and demographic residential clusters according to Kruskall-Wallis statistical test and Dunn's post hoc multiple pairwise comparison in the Helsinki Metropolitan Area (HMA).

\begin{tabular}{l|c|c}
\hline Sub-population group & Kruskall-Wallis test & Dunn's test z-score \\
\hline Swedish language & $* * *$ & $-13.03(* * *)$ \\
Median income & $* * *$ & $-12.49(* * *)$ \\
High level of education & $* * *$ & $-8.54(* * *)$ \\
Age over 65 & $* * *$ & $-6.83(* * *)$ \\
Foreign language & $* * *$ & $11.24(* * *)$ \\
Low level of education & $* * *$ & $10.96(* * *)$ \\
Finnish language & $* * *$ & $10.78(* * *)$ \\
Age under 18 & $* * *$ & $9.26(* * *)$ \\
\hline
\end{tabular}

$* * *$ is statistically sig. $p<0.001$

the employees had a low level educational background. These areas are also characterized by low median income areas.

Correspondingly Kauniainen, smallest city with a total area of $6 \mathrm{~km}^{2}$, contained rather high Swedish-speaking population clusters (38\%). In addition, clusters of high median income and high level of education were more frequently found there, in contrast to Vantaa in particular.

\section{Proximity of socio-demographic residential clusters to urban waters}

Statistical testing revealed significant differences in distances to water areas for all studied population clusters (Kruskall-Wallis test; $p$ <0.001) (Table 2). Dunn's test negative z-score showed that high value clusters, in particular population groups, were situated closer to waters compared to low value clusters. According to the results, residential areas related to the high socio-economic status were mostly found in the immediate proximity of urban waters. Additionally, areas with a high proportion of people aged over 65 and speaking the Swedish language seem to be located closer to water. The most significant difference between high and low clusters was within the Swedish language and median income group z-scores, being -12.49 and -13.03 respectively. Correspondingly areas including a high proportion of foreign language speakers, low levels of education, Finnish language speakers and age groups below 18 were situated further away from blue areas. 
Box plotting the clusters against the distance to the nearest water areas shows the distance variation (i.e. quartiles) in metric units between different population clusters in the HMA (Fig. 4). Clusters of the high median income and the Swedish language were found closest to water areas, with two thirds of the clusters situated within $1 \mathrm{~km}$ of the water. For comparison, in the high clusters of Finnish speakers and foreign language, groups below the $1 \mathrm{~km}$ threshold occurred in less than $50 \%$ of the clusters. Most of high Swedish language speaking clusters were quite evenly distributed within $830 \mathrm{~m}$ from the water with the median value being $400 \mathrm{~m}$. High clusters of median income were the closest group to water, with a median value of $270 \mathrm{~m}$ and $25 \%$ of the clusters situated within $70 \mathrm{~m}$ of the water.

Significant differences were also noticed in education level and age groups. People with a low educational background lived twice as far from water compared to highly educated people. Similar differences were noted between the age groups: people over 65 years lived closer to water compared to ages below 18, with the median distance values of $510 \mathrm{~m}$ and $1070 \mathrm{~m}$ respectively.

\section{Discussion}

In this paper we have presented the results from a study that identified differences in how various population groups with different socio-economic and demographic background reside in the four different municipalities of the HMA, and in distances of these population groups in relation to the nearest urban water areas. These differences are essential prerequisites for urban environmental justice, particularly to the accessibility and usability of blue environments in the area (cf. Kuhlicke et al. 2012; Kabisch \& Haase 2014; Hoffimann et al. 2017). We list here our three key findings and conclusions related to these results and illuminate questions on how this continuum can be altered, specifically with regard improving spatial planning of blue spaces from the perspective of distributive justice and the opportunities and means to pay more attention to the socio-cultural and demographic aspects relevant in promoting well-being and welfare through interaction with nature in urban areas.

First finding regarding the socio-economic conditions as a whole showed groups with high income and high educational background were more likely to reside close to water than their peers. Part of the reason for this is the generally higher price level of housing near water (Luttik 2000; cf. discussion by Tobias 2013). This is especially apparent at the seashore in Espoo and Helsinki whereas in Kauniainen and Vantaa the direct contact to the Baltic Sea is not present. The interpretation of this apparent inequity in access to blue areas calls for attention to be paid to possibilities for compensating for the other groups to enjoy blue environments. Such possibilities may include public transport, secured public access, organized recreational visits, and restoration of blue areas (Mekala et al. 2015). Directing these actions to concern especially inland residents in HMA, it may be possible to achieve, for instance, considerable health benefits by increasing the accessibility to coasts or other smaller water areas for various population groups, as shown by Wheeler and colleagues (2012), even though not all groups would reside on the seafront.

Second finding concerning linguistic and ethnic factors showed that Swedish were more likely to reside closer to water than native Finnish or foreign language speakers. The associated distributions with regard to the ethnic background showed high clustering especially in the eastern parts of Helsinki that correlates with lower socio-economic conditions. This noticed regional trend initiated already in the 1990s and is ongoing (Kortteinen \& Vaattovaara 2015). Although many native Finns still reside in the eastern parts of Helsinki, the emigration is increasing that may enhance the undesirable impacts that are already visible in the region (Vilkama et al. 2014). These findings were in line with the findings by Kabisch and Haase (2014). We believe that this is particularly relevance due to its topicality, both in Finland and other countries and poses the question of whether immigrants to a new country could be more thoroughly and successfully integrated through direct contact with nature, in both blue and green areas. Could access and engagement be provided for these groups not only to blue areas in the immediate surroundings of their homes but also elsewhere in the area? How could their cultural backgrounds notably regarding waters (e.g. fishing) be best utilized, not only as a challenge but also as a resource? Could their engagement with blue areas be a part of improvements in social cohesion and communication with other groups? Could 


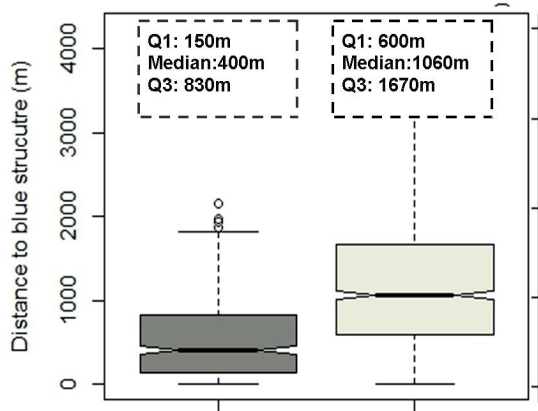

High clusters

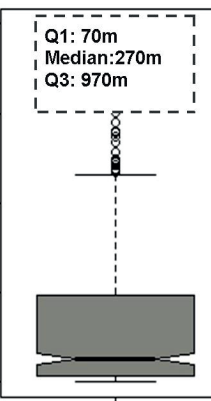

High clusters

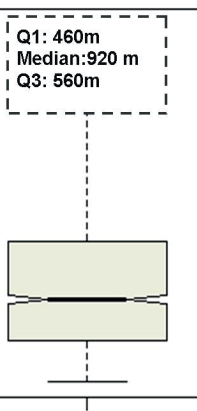

Low clusters

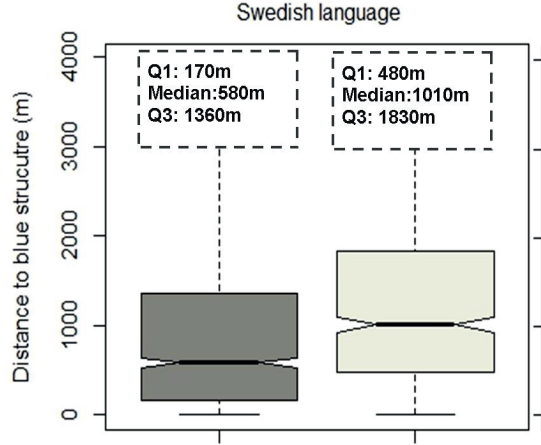

High clusters

Low clusters

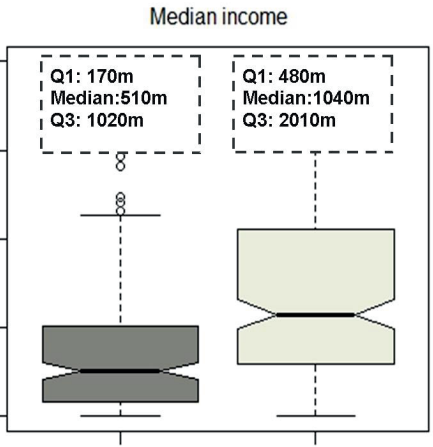

High clusters Low clusters

Age over 65

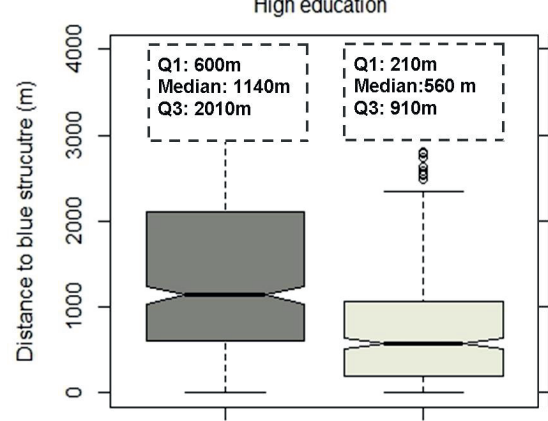

High clusters

Low clusters

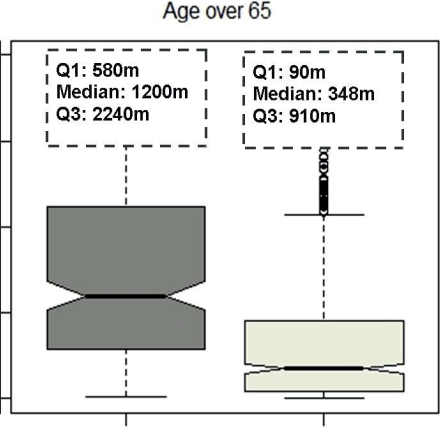

High clusters

Low clusters

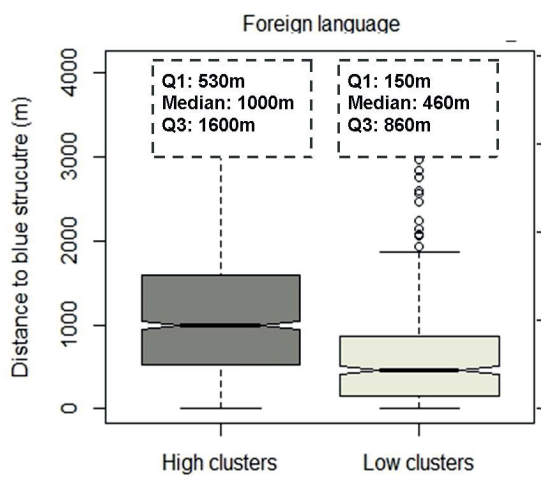

Finnish language

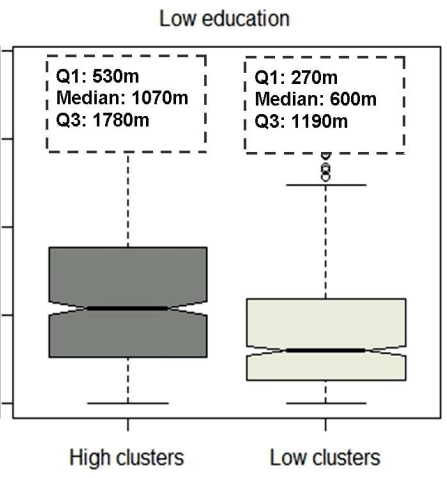

Age under 18
Fig. 4. Cluster distances to water areas in the studied socioeconomic and demographic population groups in the Helsinki Metropolitan Area (HMA).] 
this be a way to avoid some of the problems of non-strategic and unmanageable transformation such in HMA leading to more divergence socioeconomic areas? These questions should be further investigated in future studies, potentially through local scale experiments embedded in communitybased planning and action processes.

Third finding of this study was that elderly people were more frequently dwelling closer to water areas than younger ones. Even though the notion reflects the opportunities for the elderly people to benefit from the cultural ecosystem services provided by the blue areas next to their homes, simultaneously the findings raise a challenge related to the living environment of children and adolescents, whose homes are remarkably less located in the vicinity of urban blue. However, these both groups, young and old, benefit from affordances and amenities in their closest neighborhood, especially for their holistic (psycho-somatic and social) health and well-being (Kaplan 1995; Antonovsky 1996; Depledge \& Bird 2009; Haubenhofer et al. 2010; Korpela et al. 2010; White et al. 2010, 2013; von Hertzen et al. 2011; Fleming et al. 2014). This discrepancy between various age groups in living conditions illustrates more generally the need to pay attention to those population groups that mostly benefit and/or are especially challenging and vulnerable in terms of the accessibility and use of urban nature, and to develop methods to integrate their perceptions, need and practices into land use planning and governance.

We made certain decisions worth mentioning related to our study. We acknowledge that the used approach was rather descriptive, and no cause-effect interpretations regarding the interlinkages between socio-economic and demographic factors and urban blue infrastructure can be made based on the findings. In addition, in the analysis we focused on residential areas and a nearby water feature that is only one aspect or dimension in urban space people use. Although the physical environment near home is usually most frequently used, also water areas near other every-day activities, such as work, school or hobbies, provide a potential to increase and diversify the use of urban water and nature as a whole.

In our analysis, all the water areas were considered equal to provide environmental goods and benefits for the residents. However, not all blue areas are equally accessible, usable and valuable to everyone. Many strips of shoreline reside on private property or on restricted public land preventing direct aquatic activities. Due to the lack of spatial data, an analysis of a free shoreline was not included in this study. In the future studies, it would be valuable to analyze how the accessibility and perceptions of accessibility influence the use of blue infrastructure and, accordingly, what are the implications of such findings to distributive environmental justice. Attempts to distinguish the free shoreline in Finland have been studied, but the method is currently applicable mostly at national level and outside dense urban areas; thus the analysis would require further data development to spatially fit in the HMA (Nikkanen 2005; Laurila \& Kalliola 2008). Including the analysis of a free shoreline along with divergent interests, perceptions, practices, and behaviors by focusing on the most vulnerable population groups highlighted in this study provides an important future research challenge that would remarkably improve the quality of urban planning to better support distributive environmental justice.

\section{Conclusions}

Socio-economic and demographic factors are inherently tied to and explaining the place of residence and its environment. In the HMA, divergent residential areas with differences in socio-economic status, linguistics and age have varying opportunities in access to and use of blue environments. A spatial analysis combined with statistics revealed that high income and high educational background, Swedish language and high age are factors that more frequently are related to living closer to water areas. At the same time children, foreigners, people having lower economic status tend to live further away from urban blue.

From the perspective of distributive environmental justice, these aforementioned findings provide important knowledge to be integrated into urban planning. The recognition of lacking opportunities for particular population groups suggests more consideration towards children, foreign language groups, and people with low socio-economic status to reduce inequality and ensure the just distribution 
of urban blue in the HMA. Based on our findings we believe that shedding light on distributive environmental justice by capturing better the perspectives, perceptions, needs, practices, and behavior of various population groups within spatial planning can remarkably support planning processes and improve their outcomes to make a significant difference in terms of just distribution of accessible and usable urban nature.

\section{Acknowledgements}

We would like to thank Leena Kopperoinen and Lasse Peltonen for participating in the research design as a part of the ENJUSTESS research project. We would also like to thank Pekka Itkonen and Daniela Hellgren for participating in the research design and data processing in earlier stages of the project, and Athanasios Votsis for providing his expert knowledge about the spatial clustering method used in this study. We would also like to thank the Academy of Finland for funding the project (263403) as a part of the Academy Programme "Sustainable Governance of Aquatic Resources (AKVA)" and the BRO project (304515) as a part of the key project funding "Forging ahead with research".

\section{References}

Agyeman, J. (2005) Sustainable Communities and the Challenge of Environmental Justice. New York University Press, New York.

Anselin, L. (1995) Local indicators of spatial association-LISA. Geographical analysis 27 93-115. https://doi.org/10.1111/j.1538-4632.1995.tb00338.x

Anselin, L., Ibnu, S. \& Youngihn, K. (2006) GeoDa: an introduction to spatial data analysis. Geographical Analysis 38(1) 5-22. https://doi.org/10.1111/j.0016-7363.2005.00671.x

Antonovsky, A. (1996) The salutogenic model as a theory to guide health promotion. Health Promotion International 11 11-18. http://dx.doi.org/10.1093/heapro/11.1.11

Aragão A., Jacobs, S. \& Cliquet, A. (2016) What's law got to do with it? Why environmental justice is essential to ecosystem service valuation. Ecosystem Services 22 221-227. https://doi.org/10.1016/j.ecoser.2016.09.012

Asakawa, S., Yoshida, K. \& Yabe, K. (2004) Perceptions of urban stream corridors within the greenway system of Sapporo, Japan. Landscape \& Urban Planning 68 167-182. http://dx.doi.org/10.1016/S0169-2046(03)00158-0

Barbosa, O., Jamie A., Tratalos, P. R., Armsworth, R. G., Davies, R., Fuller A., Johnson, P. \& Gaston, K. J. (2007) Who benefits from access to green space? A case study from Sheffield, UK. Landscape \& Urban Planning 83 187-195. https://doi.org/10.1016/j.landurbplan.2007.04.004

Boone, C. G., Buckley, G. L., Grove, J. M. \& Chona, S. (2009) Parks and people: an environmental justice inquiry in Baltimore, Maryland. Annals of the Association of American Geographers 99(4) 767-787. https://doi.org/10.1080/00045600903102949

Bullard, R. D. (2000). Dumping in Dixie: Race, Class, and Environmental Quality. $3^{\text {rd }}$ ed. Westview Press, Boulder, CO.

Campbell, S. (1996). Green cities, growing cities, just cities?: Urban planning and the contradictions of sustainable development. Journal of the American Planning Association 62(3) 296-312. http://dx.doi.org/1080/01944369608975696

Chawla, L., Keena, K., Pevec, I. \& Stanley, E. (2014) Green schoolyards as havens from stress and resources for resilience in childhood and adolescence. Health \& Place 28 1-13. http://dx.doi.org/10.1016/j.healthplace.2014.03.001

Corraliza, J. A., Collado, S. \& Bethelmy, L. (2012) Nature as a moderator of stress in urban children. Procedia - Social and Behavioral Sciences 38 253-263.

http://dx.doi.org/10.1016/j.sbspro.2012.03.347

Dadvand, P., Nieuwenhuijsen, M.J., Esnaola, M., Forns, J., Basagañ, A. X., Alvarez-Pedrerol, M., Rivas, I., López-Vicente, M., De Castro Pascual, M., Su, J., Jerrett, M., Querol, J. \& Sunyer, J. (2015) Green spaces and cognitive development in primary schoolchildren. PNAS 112(26) 7937-7942. https://doi.org/10.1073/pnas.1503402112

Daniel, T. C., Muhar, A., Arnberger, A., Aznar, O., Boyd, J. W., Chan, K. M. A., Costanza, R., Elmqvist, T., Flint, C. G., Gobster, P. H., Grêt-Regamey, A., Lave, R., Muhar, S., Penker, M., Ribe R. G., Schauppenlehner, T., Sikor, T., Soloviy, I., Spierenburg, M., Taczanowska, K., Tam, J. \& von der 
Dunk, A. (2012) Contributions of cultural services to the ecosystem services agenda. PNAS 109(23) 8812-8819. http://dx.doi.org/10.1073/pnas.1114773109

Davidson, M. D. (2012) Distributive justice in the international regulation of global ecosystem services. Global Environmental Change 22(4) 852-861.

http://dx.doi.org/10.1016/j.gloenvcha.2012.06.004

Davis, A. Y., Belaire, J. A., Farfan, M. A., Milz, D., Sweeney, E. R., Loss, S. R. \& Minor, E. S. (2012) Green infrastructure and bird diversity across an urban socioeconomic gradient. Ecosphere 3(11) 1-18. http://dx.doi.org/10.1890/ES12-00126.1

Depledge, M. H. \& Bird, W. J. (2009) The blue gym: health and well-being from our coasts. Marine Pollution Bulletin 58 947-948. https://doi.org/10.1016/j.marpolbul.2009.04.019

Dinno, A. (2016) dunn.test: Dunn's test of multiple comparisons using rank sums. R package version 1.3.3. <http://CRAN.R-project.org/package=dunn.test $>$

Dunn, O. J. (1964) Multiple comparisons using rank sums. Technometrics 6(3) 241-252. http://dx.doi:10.2307/1266041

Ernstson, H. (2013) The social production of ecosystem services: a framework for studying environmental justice and ecological complexity in urbanized landscapes. Landscape \& Urban Planning 109(1) 7-17. http://dx.doi.org/10.1016/j.landurbplan.2012.10.005

Fleming, L. E., McDonough, N., Austen, M., Mee, L., Moore, M., Hess, P., Depledge, M. H., White, M., Philippart, K., Bradbrook, P. \& Smalley, A. (2014) Oceans and human health: a rising tide of challenges and opportunities for Europe. Marine Environmental Research 99 16-19. http://dx.doi.org/10.1016/j.marenvres.2014.05.010

Haubenhofer, D. K., Elings, M., Hassink, J. \& Hine, R. E. (2010) The development of green care in WesternEuropeanCountries.Explore6106-111.http://dx.doi.org/10.1016/j.explore.2009.12.002

Helsingin kaupungin rakennusvirasto [Public works department of City of Helsinki] (2007) Helsingin pienvesiohjelma [Programme of small water areas in Helsinki]. Helsingin kaupungin rakennusviraston julkaisut 3 [Publications of the Public works department of City of Helsinki 3]. Sokonet Oy, Espoo. [in Finnish]

von Hertzen L., Hanski I. \& Haahtela T. (2011) Natural immunity. Biodiversity loss and inflammatory diseases are two global megatrends that might be related. EMBO Reports 12 1089-1093. https://doi.org/10.1038/embor.2011.195

Heynen, N., Perkins, H. A. \& Parama, R. (2006) The political ecology of uneven urban green space. Urban Affairs 42(1) 3-25. https://doi.org/10.1177/1078087406290729

Hoffimann, E., Barros, H., \& Ribeiro, A. I. (2017). Socioeconomic inequalities in green space quality and accessibility-Evidence from a Southern European city. International Journal of Environmental Research and Public Health 14(8) 916. http://doi.org/10.3390/ijerph14080916

Jennings, V., Gaither, C. J. \& Gragg, R. S. (2012) Promoting environmental justice through urban green space access: a synopsis. Environmental Justice 5(1) 1-7. http://dx.doi.org/10.1890/ES12-00126.1

Kabisch N. \& Haase D. (2014) Green justice or just green? Provision of urban green spaces in Berlin, Germany. Landscape \& Urban Planning 122 129-139.

http://dx.doi.org/10.1016/j.landurbplan.2013.11.016

Kaplan, S. (1995) The restorative benefits of nature: toward an integrative framework. Journal of Environmental Psychology 15 169-182. http://dx.doi.org/10.1016/0272-4944(95)90001-2

Kekez, V. (2015) Clustering of immigration population in Helsinki Metropolitan Area, Finland: a comparative study of exploratory spatial data analysis methods. Master's thesis in Geoinformatics.UniversityofHelsinki, Helsinki.https://helda.helsinki.fi/handle/10138/153114

Korpela, M. K., Ylén, M., Tyrväinen, L. \& Silvennoinen, H. (2010) Favourite green, waterside and urban environments, restorative experiences and perceived health in Finland. Health Promotion International 25 200-209. https://doi.org/10.1093/heapro/daq007

Kortteinen, M. \& Vaattovaara, M. (2015) Segregaation aika. Yhteiskuntapolitiikka 80(6) 563-574.

Kuhlicke, C., Kabisch, S., Krellenberg, K. \& Steinführer, A. (2012) Urban vulnerability under conditions of global environmental change: conceptual reflections and empirical examples from growing and shrinking cities. In Kabisch, S., Kunath, A., Schweizer-Ries, P. \& Steinführer, A. (eds.) Vulnerability, Risks and Complexity: Impacts of Global Change on Human Habitats, 2738. Göttingen, Hogrefe.

Laatikainen, T., Piiroinen, R., Lehtinen, E. P. \& Kyttä, M. (2017) PPGIS approach for defining multimodal travel thresholds: accessibility of popular recreation environments by the water. Applied Geography 79 93-102. http://dx.doi.org/10.1016/j.apgeog.2016.12.006 
Laatikainen, T., Tenkanen, H., Kyttä, M., \& Toivonen, T. (2015) Comparing conventional and PPGIS approaches in measuring equality of access to urban aquatic environments. Landscape \& Urban Planning 144 22-33. http://dx.doi.org/10.1016/j.landurbplan.2015.08.004

Laurila, L. \& Kalliola, R. (2008) Rakennetut meren rannat 2005 [The Developed Coastline 2005]. Ympäristöministeriön raportteja 3 [Reports of the Ministry of the Environment 3]. Ympäristöministeriö [Ministry of the Environment], Helsinki. <https://julkaisut.valtioneuvosto. fi/bitstream/handle/10138/41405/YMra3_2008_Rakennetut_meren_rannat_2005. pdf? sequence $=2>$ [in Finnish]

Lehtomäki, E. (2015) Kansalaisten osallistumismahdollisuuksien kehitys Helsingin rantojen suunnittelussa [Citizen participation in developing shorelines in Helsinki]. Ympäristön ja alueiden politiikan pro gradu -tutkielma [Master's thesis]. Tampereen yliopisto [University of Tampere], Tampere. https://tampub.uta.fi/handle/10024/97058 [in Finnish]

Luttik, J. (2000) The value of trees, water and open space as reflected by house prices in the Netherlands. Landscape \& Urban Planning 48 161-167. http://dx.doi.org/10.1016/S0169-2046(00)00039-6

Maas, J., Verheij, R. A., Groenewegen, P. P., de Vries, S. \& Spreeuwenberg, P. (2006) Green space, urbanity, and health: how strong is the relation? Journal of Epidemiology and Community Health 60(7) 587-592. http://doi.org/10.1136/jech.2005.043125

McConnachie, M., Shackleton, C. M. \& McGregor, G. K. (2008) The extent of public green space and alien plant species in 10 small towns of the sub-tropical thicket biome, South Africa. Urban Forestry \& Urban Greening 78(1) 1-13. https://doi.org/10.1016/j.ufug.2007.12.003

McDonald, J. H. (2014) Handbook of Biological Statistics. $3^{\text {rd }}$ ed. Sparky House Publishing, Baltimore, MD.

Mekala, G. D., Jones, R. N. \& MacDonald, D. H. (2015) Valuing the benefits of creek rehabilitation: building a business case for public investments in urban green infrastructure. Environmental Management 55(6) 1354-1365. http://doi.org/10.1007/s00267-015-0471-7

Millennium ecosystem assessment (2005) Ecosystems \& Human Well-being: Synthesis. Island Press, Washington, D.C.

Mitchell, R., Astell-Burt, T. \& Richardson, E. A. (2011) A comparison of green space measures for epidemiological research. Journal of Epidemiology Community \& Health 65 853-858. http://dx.doi.org/10.1136/jech.2010.119172

Nikkanen, M. (2005) Vapaat rannat-kartoitus [Survey on open shorelines]. Julkaisematon raportti [Unpublished report]. Turun kaupunki [City of Turku], Turku. [in Finnish]

Patrick, M.J., Syme, G.J. \& Horwitz, P. (2014) How reframing a water management issue across scales and levels impacts on perceptions of justice and injustice. Journal of Hydrology 519 2475-2482. http://dx.doi.org/10.1016/j.jhydrol.2014.09.002

Pohlert, T. (2016) The pairwise multiple comparison of mean ranks package (PMCMR). R package. $<$ http://CRAN.R-project.org/package $=P M C M R>$.

R Core Team (2013) R: A language and environment for statistical computing. R Foundation for Statistical Computing, Vienna, Austria. <http://www.r-project.org/>.

Ruokolainen, L., von Hertzen, L., Fyhrquist, N., Laatikainen, T., Lehtomäki, J., Auvinen, P., Karvonen, A. M., Hyvärinen, A., Tillmann, V., Niemelä, O., Knip, M., Haahtela, T., Pekkanen, J. \& Hanski, I. (2015) Green areas around homes reduce atopic sensitization in children. Allergy: European Journal of Allergy and Clinical Immunology 70(2) 195-202. https://doi.org/10.1111/all.12545

Schaerer, C. \& Baranzini, A. (2009) Where and how do Swiss and foreigners live? Segregation in the Geneva and Zurich housing market. Swiss Journal of Sociology 35 571-592. http://dx.doi.org/10.2139/ssrn.1281200

Sister, C., Wilson, J. \& Wolch, J. (2006) Access to parks and park facilities in the green visions plan region. University of Southern California GIS Research Laboratory and Center for Sustainable Cities 17. Los Angeles, California.

Spinney, J. E. L. \& Millward, H. (2013) Investigating travel thresholds for sports and recreation activities. Environment and Planning B: Urban Analytics and City Science 40(3) 474-488. https://doi.org/10.1068/b37161

Strandell, A. (2017) Asukasbarometri 2016 - Kysely kaupunkimaisista asuinympäristöistä [Residents' barometer 2016 - Survey of the quality of local urban environments and housing]. Suomen Ympäristökeskuksen raportteja 19 [ Reports of the Finnish Environment Institute 19]. Suomen Ympäristökeskus [Finnish Environment Institute], Helsinki. [in Finnish] 
Takano, T., Nakamura, K. \& Watanabe, M. (2002) Urban residential environments and senior citizens' longevity in megacity areas: importance of walkable green spaces the. Journal of Epidemiology \& Community Health 56 913-918. http://dx.doi.org/10.1136/jech.56.12.913

Tobias, S. (2013) Preserving ecosystem services in urban regions: challenges for planning and best practice examples from Switzerland. Integrated Environmental Assessment and Management 9(2) 243-251. https://doi.org/10.1002/ieam.1392

Tobler, W. (1970) A computer movie simulating urban growth in the Detroit region. Economic Geography 46(2) 234-240. http://dx.doi.org/10.1002/ieam.1392

Tyler, T. (2000) Social justice: Outcome and procedure. International Journal of Psychology 35(2) 117-125. http://dx.doi.org/10.1080/002075900399411

Tzoulas, K., Korpela, K., Venn, S., Yli-Pelkonen, V., Kaźmierczak, A., Niemela, J. \& James, P. (2007) Promoting ecosystem and human health in urban areas using green infrastructure: a literature review. Landscape \& Urban Planning 81(3) 167-78. http://dx.doi.org/10.1016/j.landurbplan.2007.02.001

Vaattovaara, M. \& Kortteinen, M.(2014)Segregaatiostaja sen inhimillisestäja yhteiskunnallisesta merkityksestä [Segregation, humanity and society]. Talous \& yhteiskunta [Economy \& Society] 40(3) 60-66. [in Finnish]

Vilkama, K. (2011) Shared city or divided neighbourhoods? Residential segregation and selective migration of the native and immigrant populations in the Helsinki Metropolitan Area. Research series 2011(2). City of Helsinki Urban Facts, Helsinki. Dissertation, University of Helsinki. https://helda.helsinki.fi/bitstream/handle/10138/28183/yhteinen.pdf?sequence=1 (in Finnish)

Vilkama, K., Lönnqvist, H., Väliniemi-Laurson, J. \& Tuominen, M. (2014) Erilaistuva pääkaupunkiseutu. Sosioekonomiset erot alueittain 2002-2012 [Socioeconomical differences in the Helsinki Metropolitan Area 2002-2012]. Tutkimuksia [Research series] 2014(1). Helsingin kaupungin tietokeskus [City of Helsinki Urban Facts], Helsinki. [in Finnish]

Völker, S. \& Kistemann, T. (2011). The impact of blue space on human health and well-being Salutogenetic health effects of inland surface waters: a review. International Journal of Hygiene and Environmental Health 214 449-460. https://doi.org/10.1016/j.ijheh.2011.05.001

Wen, M., Zhang, X., Harris, C. D., Holt, J. B. \& Croft, J. B. (2013) Spatial disparities in the distribution of parks and green spaces in the USA. Annals of Behavioral Medicine 45 18-27. http://dx.doi.org/10.1007/s12160-012-9426-x

Wheeler, B. W., Mathew, W., Stahl-Timmins, W \& Depledge, M. H. (2012) Does living by the coast improve health and wellbeing? Health \& Place 18(5) 1198-1201. http://dx.doi.org/10.1016/j.healthplace.2012.06.015

White, M., Alcock, I., Wheeler, B. W. \& Depledge, M. H. (2013) Coastal proximity, health and well-being: results from a longitudinal panel survey. Health \& Place 23 97-103. http://dx.doi.org/10.1016/j.healthplace.2013.05.006

White, M., Smith, A., Humphryes, K., Pahl, S., Snelling, D. \& Depledge, M. (2010) Blue space. The importance of water for preference, affect and restorativeness ratings of natural and built scenes. Journal of Environmental Psychology 30 482-493. http://dx.doi.org/10.1016/j.jenvp.2010.04.004

Wickham, H. (2009) ggplot2: Elegant Graphics for Data Analysis. Springer, New York.

Wolch, J. R., Byrne, J. \& Newell, J. P. (2014) Urban green space, public health, and environmental justice: The challenge of making cities 'just green enough'. Landscape and Urban Planning 125 234-244. http://dx.doi.org/10.1016/j.landurbplan.2014.01.017

Wolch, J., Jerrett, M., Reynolds, K., McConnell, R., Chang, R., Dahmann, N., Brady, K., Gilliland, F., Su, J. G. \& Berhane, K. (2011) Childhood obesity and proximity to urban parks and recreational resources: a longitudinal cohort study. Health \& Place 17 207-214. https://doi.org/10.1016/j.healthplace.2010.10.001 